\title{
Ernst Baltrusch, Hans Kopp, Christian Wendt (eds.), Seemacht, Seeherrschaft und die Antike (Historia Einzelschriften - 244), Franz Steiner Verlag, Stuttgart 2016, pp. 348, ISBN 978-3-515-11431-8
}

The issues surrounding the presence of Greeks and Romans at sea are a popular subject among scholars. This interest is entirely natural, as the sea occupied an important place in their culture, religion, and economic and military activity. This is also confirmed by a large amount of material and written evidence. Interpreting these sources is no easy task, however, as they came from various periods and places. As a result, although their authors employ similar concepts, these do not always have the same meaning that is usually ascribed to them. There is therefore a risk of misunderstanding the phenomena that they describe, leading to incorrect interpretation. The great diversity of these phenomena over time means that a collaborative effort is necessary for assessing them appropriately. An example of such cooperation is the international conference that took place in December 2013 at Freie Universität Berlin, whose objective was to examine marine affairs in antiquity from a broad time perspective. In this case, it essentially encompassed the issues and events that took place in Greece from the Archaic to the Hellenistic period, and in Rome at the time of the Republic and Empire. The Franz Steiner Verlag has now published the proceedings of the conference, whose 15 articles - 11 in German and four in English - provide an insight into the contents presented there.

The main objectives of the conference are defined by its organisers (E. Baltrusch, H. Kopp, C. Wendt) in the introduction (Einleitung, pp. 9-23). They are worth listing here, as they shaped the form of the publication. The first was to clarify the meaning of the concept of thalassokratia, frequently used by Greek authors. One of the difficulties with interpreting this word is that it is impossible to render it precisely in contemporary languages. Consequently, although for many scholars it is generally a synonym of domination at sea, ancient authors used it in various meanings and contexts. They employed it to mean states with considerable marine forces allowing them to control vast stretches of water, but also other actions associated with activity at sea. Moreover, analysis of the sources sometimes leads to the conclusion that the semantic meaning of the concept thalassokratia as used by them tended not to have much to do with the historical reality they were describing. The papers tackling this matter are collected in the first part of the volume, titled Der Zugriff auf das Meer (H. Kopp, Thalassokratie: Zur historischen Semantik und Wirkungsgeschichte eines Hilfsbegriffs, pp. 27-46; M. Rathmann, Das Meer bei den antiken Geographen, pp. 47-77; C. Wendt, Piraterie als definitorisches Moment von Seeherrschaft, pp. 79-92; B. Strauss, Thucydides, Polybius and Mahan on Sea Power, pp. 93-99). 
The conference's second aim was to examine the question of the marine activity of the ancient peoples not only through historical evidence, but also through research methods adopted in other disciplines (archaeology, philosophy), using them to point to new directions of research and the particular characteristics of specific historical periods. The third objective was to use selected examples to identify the possibilities of going beyond the framework of the previously analysed canon of topics, and highlight those which had not been given due attention. The fourth was to demonstrate the broader significance of marine issues, apart from the narrow question of dominance at sea.

Except for the group of articles concerning terminological issues in the first part of the book, the others are sorted into three other subject areas. Part Two, titled Operative Konzeptionen, contains articles on certain political and strategic concepts associated with the sea policy of Athens and Rome: K.A. Raaflaub, 'Archē', 'Reich' oder 'athenische Groß-Staat'? Zum Scheitern integrativer Staatsmodelle in der griechischen Poliswelt des 5. und frühen 4. Jahrhunderts v. Chr., pp. 103-132; J. Wilker, 'That All Your Security Depends on the Sea': The Concept of Hegemony at Sea in Fourth-Century Athens, pp. 133-149; R. Schulz, Das Meer im strategischen Denken der Römischen Republik, pp. 151-162; B. Linke, Die Republik und das Meer. Seerüstung und römische Innenpolitik zur Zeit der Punischen Kriege, pp. 163-185.

Part Three (Grenzen des Kanons) is the shortest, with only two articles. These concern the issue of Sparta and Judaea's presence at sea. In both cases, this is distinctly underappreciated. M. Dreher (Die Seemacht Sparta, pp. 189-204) demonstrates just how important a role in Sparta's rivalry with Athens in the fifth and early fourth century BCE was played by the state's activity at sea. He divides this into five phases, of which especially the third (477-412 BCE) and fourth (412-404 BCE) were important, as it was then that Sparta's sea power grew, something that would prove decisive in victory over Athens in the Peloponnesian War. Sparta's strength in this area was short-lived, however, as it was lacking the resources to maintain the required marine infrastructure and a sizable fleet. In the second article, M. Schuol (Jüdische Seemacht?, pp. 205-215) discusses the activity of Jews at sea, from biblical times to the first century CE. There are many surviving references to this activity. Apart from brief periods, however, these do not suggest that they were of great political or economic significance for Jewish interests. A change came in this respect only in the times of Herod, who invested a great deal of effort and funds in the expansion of ports. In the final reckoning, it was Rome that benefited from his accomplishments.

The Fourth and final part of the book (Selbstwahrnehmung und Repräsentation) consists of five articles (S. Müller, Die Perser und das Meer: Eine Analyse der Inschriften der frühen Perserkönige, pp. 219-231; M. Trümper, Delos as Center of Athenian 'Sea Power' - An Archaeological Perspective, pp. 233-251; D. Kah, Rodos als Seemacht, pp. 253-277; V. Fabrizi, Space, Vision and the Friendly Sea: Scipio's Crossing to Africa in Livy's Book 29, pp. 279-289; E. Baltrusch, 'Hier war doch eben noch Land'-Naumachien in Rom, pp. 291-304). Although each of these takes a selected problem as its subject, they are linked by a shared characteristic - in analysing different aspects of marine issues, their authors endeavour to address their propaganda, political and economic aspects. Their importance cannot be underestimated, as it is reflected in the manifestation of the political and military might of Persia, Athens, Rhodes and Rome. 
It is hard to pick out any of the texts for particular praise; they are all part of a complete whole, each of them worth reading and reflecting on. It is necessary to do so to fully appreciate the role of the sea factor in the history of specific cities and states, but also entire eras. There is no doubt that its power was not always identically large and its influence strong, since particular states' ability to secure domination at sea and maintain sea power was determined by their economic potential. Several authors point to this important role of the economic factor in deciding upon the size of fleet a state possessed, and the subsequent possibilities of its military use. Maintaining a sizable and proficient fleet and the essential technical infrastructure to ensure its operation entailed huge costs. And it was the lack of sufficient funds, rather than of the demographical potential needed for manning the ships, that often prevented even the large city-states of Greece from long-term domination at sea. The difference in the political situation in the Greek world from that in the Roman world meant that the role of the sea factor was different in the latter. It would certainly be justified to pay attention to the economic aspect of domination at sea in further studies on the marine history of the ancient world.

The articles in this volume can be recommended as an introduction to issues of domination at sea and the role of this factor in shaping the history of certain Greek states. In the case of the marine history of Rome, the texts in the book, with one exception, are mostly about the period of the Republic. The subjects they tackle mean that they too will prove to be of interest.

Edward Dąbrowa (Jagiellonian University in Kraków) 